\title{
The Scholarly Monograph Unbound
}

Predicting the future has a discouraging history. Pronouncements about media have been especially prone to "spectacular failures of foresight," as George Bornstein claims.' That risk surely doubles when prognosticating about the future of books, whose histories and transdiscursive identities resist definition by even advanced textual scholars. Widespread questions about book futures have given a recent charge to the field of book history with its ongoing work to think through the material, economic, and discursive contexts of textual production, transmission, and reception. Those perspectives may also help extrapolate what lies ahead as the boundaries of the "book" are redrawn in a new media landscape, its circuitry rewired to the institutional and social conditions of an increasingly digital age. As Ken Wissoker argues, "this is a transitional, even disruptive and disrupted, moment in the history of the book," not just as an object of scholarly inquiry, but as a form and practice of scholarly communication. ${ }^{2}$ As the editorial director of Duke University Press, Wissoker is particularly interested-like this essay-in the mediated future of academic publishing.

But first: what is a book? Considering the problem of even defining the term, David Greetham observes that "[o]ne cannot help but sense an entropic weariness, in which book is so very ubiquitous that it can no longer be pinned down. ${ }^{{ }^{3}}$ When we talk about books, we are dealing with a voluminous lot of overlapping intellectual and commercial domains which adds to the numbing complexities of predicting their futures. The ubiquity of book futurism can impart a weariness of its own: "If I read yet another article entitled 'The Future of the Book' I think I'll die of boredominduced perennial lethargy," tweets Elena Pierazzo. ${ }^{4}$ Nonetheless, we have reached a crucial time in the evolution of the book, whose adaptation in the academic environment will significantly be determined by what scholars propose to do with it, even if they are spectacularly wrong. This essay tries to separate the future of the scholarly monograph from book futures in general, in order to speculate about the "book" in a fairly specific sense. So let me begin with a simplification: for humanities scholars, books can mean things we study, things we use, and things we make. I will address the last category about scholars making books and, in particular, the textual editions and research-based monographs that humanities scholars have been in the business of publishing, typically with academic publishers and university presses. "Books" as in the question a colleague or tenure committee might ask: "Does he have a book?" Not meaning is he carrying one, but has he published.

Talking about books this way refers to a particular form of scholarly production and communication, one that, along with the peer-reviewed journal, has predominated for the last half century, at least in the United States. A book in this sense should be thoroughly researched, peer reviewed, edited and published by a respectable press, conforming to what the historian Dan Cohen calls "the social contract" of scholarly publishing. ${ }^{5}$ Seen this way, the "book" is a set of 
informational and material practices that embody a given set of scholarly values, particularly within disciplines in the humanities and social sciences. For academics in these fields, to publish a book demonstrates that its author subscribes to said contract and values, just as much as they contribute to the intellectual community of a discipline. And so publishing is like passing a test, which has made the scholarly monograph nearly synonymous with the aspirations of tenure and promotion within the research university, especially for junior faculty. "The book" in this sense is a gatekeeper and credentialing mechanism for the academy. Publishing industry veteran Phil Pochoda charts the transactions of the "book" within a scholarly communications circuit whose primary functions are authorization and accreditation. ${ }^{6}$ The book is "the marketable commodity [...] regarded quite properly as the smallest unit of 'publication' discourse" for publishers and as a significant unit of professional currency for academic authors. 'These functions have profoundly shaped the genre we even call the scholarly monograph. Indeed, they may be the last things keeping the scholarly monograph alive.

It is common to remark that the monograph suffers an increasingly critical condition. ${ }^{8}$ Library budgets are shrinking, university presses are being shuttered or shifting their priorities elsewhere, and scholars are exploring new digital forms of production and communication. Certainly university presses and their parent organizations have been worried, as apparent in the more conspicuous forums in which they speculate about the future: Crises and Opportunities: The Futures of Scholarly Publishing, "University Press Forum: Variations on a Digital Theme," "University Publishing in a Digital Age," "Reimagining the University Press," "Imagining a University Press System to Support Scholarship in the Digital Age," Sustaining Scholarly Publishing: New Business Models for University Presses. ${ }^{9}$ The title keywords alone register the seriousness of this transitional moment, also suggesting that, for university presses at least, it takes real work to "reimagine" this as an opportunity. These reports do consistently focus on the digital horizon for a variety of financial, infrastructural, and intellectual reasons. But as Pochoda argues, "nothing resembling a digital scholarly publishing system has yet coalesced, or even dimly revealed its initial configuration."

The initial efforts to reimagine the humanities monograph within the digital realm have been starkly unimaginative: turning books into eBooks, or offering digital versions of monographs in formats like PDF, EPUB, etc., ready for screens and mobile-reading devices. As a scholar who frequently uses such texts for research, I appreciate their availability but have been dismayed by the clunkiness and foreshortened imaginative horizons of eBooks as such. As Bornstein argues, "[t]his immense gain in accessibility has come at the price of neglecting possibilities for new forms of scholarship" as well as the privileging of the "linguistic code" over the manifold functions of books. ${ }^{11}$ John Siracusa has even suggested that the biggest problem with eBooks is the legacy of their name, distracting publishers from the uniqueness of electronic formats and how remediating books profoundly changes the ways we use them. ${ }^{12}$ The last thing we do with a book onscreen is to "read" it. By contrast, "reading" a paper book was never really just reading, but a complex mixture of nonlinear information uptake, manual annotation, on-the-fly mnemonic indexing, ocular 
collation, and ambient findability. To describe reading with such techno-jargon is to defamiliarize the book as itself a technology-and one whose complex feature sets have been ignored in favor of its apparent "text." As has been demonstrated by book history and media studies, reading is a complex and historically-determined set of practices; we need likewise to examine our own scholarly text technologies in this light. But as numerous commentators suggest, the dynamic affordances of print technology have yet to be electronically reimagined or effectively remediated. As we interface with new and diverse scholarly objects, call them whatever, these subroutines of reading and research have also to be reinvented in whatever forms or platforms publishing deploys.

The impetus for this change must start with scholars themselves. Monica McCormick, director of the New York University Press, suggests that the scholarly monograph will have a future "so long as there's an intellectual purpose. [...] The scholarly community has to decide what it wants the monograph as a form to do. ${ }^{13}$ It will not be sustainable to use the book as an authorizing and accrediting tool. Meredith Morris-Babb, director of University of Florida Press, explains that university presses got wrapped up in the academic evaluation process but really do not want to be there: "no one's promotion should depend on our business model." ${ }^{14}$ Universities and professional organizations have been gradually responding with revised promotion guidelines, including the MLA's report from its "Task Force on Evaluating Scholarship for Tenure and Promotion" and its "Guidelines for Evaluating Work with Digital Media." These changes were initially targeted at more economically and professional sustainable forms of scholarly output, but they are increasingly attentive to the diversification of that output within a new media landscape. The book's future functions might be usefully recalibrated within this broader context of digital forms and humanities information practices.

A 2011 Research Information Network report explains that "researchers [are] working with new tools and technologies, in increasingly collaborative environments, and both producing and using information resources in diverse ways. There is a richness and variety within humanities information practices." ${ }^{15}$ Here is the optimistic angle on the future. Instead of the Spencerian struggle for life and survival of the fittest academic publisher, the RIN reports the "richness and variety" within a changing media ecology. We shall not fear the evolution or even extinction of published species, for there is grandeur in this view of academic life. Thus, instead of only contemplating the book's future, we ought to consider the broader context of how scholarly information practices are changing. To call the book an "information practice" distorts its rich material and epistemological histories, but we may have arrived at such a moment of rupture. As Craig Mod claims, "[t]he think about the future of the book is to think about the future of all content" as well as its systems of generation, transmission, and continuing usage. ${ }^{16}$ Pochoda goes even farther: "What is underway is not just a change in formats and publication processes, but a much more fundamental, ontological, change in what it means to be a participant [...] in a digital scholarly publishing system." ${ }^{17}$ 
Economic, epistemological, ontological: the seeming consequences for book futures are complex and far-reaching. What might this look like in practice? Among the groundbreaking examples comes from Kathleen Fitzpatrick, a media studies professor and author of Planned Obsolescence: Publishing, Technology, and the Future of the Academy. Fitzpatrick's monograph was published by NYU Press, but her "book" first appeared as a draft manuscript online, built on the blog-like CommentPress platform developed by the Institute for the Future of the Book. On the web, Planned Obsolescence was open for public comment, allowing for give-and-take between readers and author in shaping the final project. ${ }^{18}$ Projects like this have been called "networked books" for the community input, open review, and dynamic curation that they involve. Those are precisely the subjects of Fitzpatrick's argument in Planned Obsolescence, which is less concerned with any specific published forms or technical platforms, and more about what scholarly values they entail. Fitzpatrick claims that the traditional publishing and evaluation regimes are out of date and must be adjusted to the intellectual and social affordances of the world wide web. Disciplines in the sciences have already begun to model such changes, adapting their publishing practices to rapid online access, including repositories of ongoing research, pre-print articles, and data sets like arXiv.org and the Social Science Research Network (SSRN) as well as peer-reviewed venues such as PLOS ONE. In advocating for similar changes in humanities publishing, Fitzpatrick now has an institutional platform as the director of the MLA's Office of Scholarly Communication-a newly established office bringing together the book publishing program and the web group, and pointedly avoiding "publication" in its name (remember "eBooks"?). Her goal is to help researchers and institutions rewire the communications circuit of scholarly publication and, just as significantly, formalize the evaluative and credentialing feedback loops that stabilize any scholarly publishing system.

The NYU Press deserves a deal of credit for backing Fitzpatrick's publishing wager. Her book proposes a motto for institutional inertia-"We Have Never Done It That Way Before"-as a challenge to publishers and academics to try to reckon creatively with our digital futures. ${ }^{19}$ Increasingly, we can find examples of academic publishers whose efforts to "reimagine" themselves in a digital age suggest interesting possibilities for the future of the book. That phrase must not only mean future forms of the book, but the institutional and economic configurations that make them possible. The "Rotunda Imprint" of the University of Virginia Press describes its mission as "the publication of original digital scholarship along with newly digitized critical and documentary editions in the humanities and social sciences. The collection combines the originality, intellectual rigor, and scholarly value of traditional peer-reviewed university press publishing." ${ }^{20}$ Note the strategically careful nod to the "scholarly value" of traditional publishing-balanced with their interests in digital scholarship and editions that are unbound by print. The Rotunda Imprint is also distinguished by its institutional hybridity with connections to UVa's Institute for Advanced Technology in the Humanities (or IATH), the library, and the innovative digital humanities center the Scholars' Lab. The University of Michigan Press offers a different case study. Trying to outmaneuver the budgetary attacks of an axe-wielding state legislature, they moved themselves to the university's academic core and proactively integrated with the university library and its 
Scholarly Publishing office. The result is "MPublishing" which declares its mission like this: "creates, promotes, distributes and preserves scholarly, educational and regional materials in digital and print formats." ${ }^{21}$ They are experimenting with print-on-demand, open access digital editions such as with their imprint digitalculturebooks, and new forms of scholarly publishing beyond the genre of the monograph, all the while keeping an eye on the unsexy but essential issues of media interoperability and preservation. Some other presses are following suit, including the Amherst College Press, based in the college library and publishing peer-reviewed, open access academic books. ${ }^{22}$

MPublishing can also accommodate out-of-print monographs, as with their faculty reprints series: a no-cost service to UM faculty who own the copyright to their book and are willing to contribute it to the HathiTrust Digital Library. MPublishing prepares these texts for digital distribution and makes print-on-demand reprints available for sale through Amazon or the library's own Espresso Book Machine. They were kind enough to mail me a sample: Robert Bartlett's Critical Care Physiology, originally published in 1996 by Little, Brown and Company, and republished by the UM Faculty Reprints Series in 2010. My copy was born in the University Library in Ann Arbor in June 2011, produced in about seven minutes on a self-service machine. It isn't what jumps to mind when thinking about having an Espresso in the library, but the machine is apparently as effective and comforting. According to Shana Kimball, an officer at MPublishing, the machine provides an unlooked-for reassurance to potential authors and library patrons; it promises tangible links to the cloud of data in familiar bibliographic forms.

My Espresso-generated copy looks and feels just like a book: not too short, not too long. But those conventional thresholds of length need less and less govern scholarly production. Many new media commentators have argued how iTunes-that killer app-radically changed the dimensions of the music industry from the album to the song. ${ }^{23}$ The analogy for scholars is the individual journal issue or edited collection which, like the album, may likewise cede to single articles or chapters, as these bound vehicles may no longer be the primary means of transmitting them. Like the shifting information practices of web users, academics and researchers are experiencing "a huge shift in the way we read," argues Gita Manaktala, Director of MIT Press. In particular, Manaktala points to shifts "from stable knowledge and stable content embodied in the codex to more dynamic forms," "from reading to a broader bandwidth understanding of attention," and "from traditional academic forms of peer review [...] to facilitated networks of review." ${ }^{24}$ The humanities monograph does not necessarily fit into environments that privilege recursive and granular searching (i.e. looking for specifics, rather than navigating through ordered hierarchies). In terms of granularity, the 160-300 page monograph may be increasingly difficult to swallow. This analogy does not intend to promote retailing individual chapters and journal articles in some online store, the iCademy, if you will. Rather, it means to provoke thinking about what units of scholarly production are feasible and best suited to new forms of transmission. 
Examples already exist in the expansive digital editions, thematic research collections, and archives whose scale alone prohibits their lives as books. For example, the Rotunda imprint publishes several of these, such as Emily Dickinson's Correspondences, with its wonderful epigraph "I had told you / I did not print." ${ }^{25}$ Most of these projects far exceed what is possible in the bounded space of print copy. At the Newfound Press at the University of Tennessee at Knoxville (which is, like MPublishing, a digital imprint of the university libraries), they resist using the term "book" at all, preferring instead to conceptualize longer form or alternative scholarly projects on their own terms ${ }^{26}$ What might be the right size for scholarship in the digital age? That depends on the technology of transmission. The book has been our killer app. What's next?

Liza Daly in a JISC report on digital monographs argues that "[t]he move towards digital publishing in an academic context has taken place largely at the level of distribution," including the University of Chicago's Bibliovault, Oxford Scholarship Online, Cambridge Books Online, and Books at JSTOR. ${ }^{27}$ But these platforms have yet to more fully imagine the diversity of published forms they could potentially support. According to Daly, "there is unmet demand in providing digital outlets for academic publications that don't neatly fall into the journal article/monograph/textbook categories." ${ }^{28}$ In summer 2011, the Mellon-funded Scholarly Communication Institute held a conference on "New-Model Scholarly Communication: Road Map for Change." Among its many useful recommendations was the need for mechanisms for "right-sizing scholarship" without presuming it has to fit the legacy dimensions of a book or an article. ${ }^{29}$ What that looks like is not yet clear, but there are possibilities emerging both from trade and academic publishing. Kindle Singles is the latest iteration of Amazon's Shorts program. What iTunes did for the song, Kindle Singles does not simply for the book or chapter or article, but for the right-sized expression of a particular idea, whatever that may be. Long-form articles are the ready example: as academics know, sometimes 10,000 words are just not enough to say all you need. Princeton University Press and Chicago University Press are each experimenting with "shorts" programs that repurpose existing content and sell chapters and excerpts from books. ${ }^{30}$ However, the "e-singles" model may not sufficiently reimagine academic short publishing on its own terms. By contrast, Palgrave will soon launch its "Pivot" program that "offers authors the flexibility of publishing at lengths between the journal article and the conventional monograph" as well as an accelerated production process. ${ }^{31}$ (For example, as part of the Pivot program's launch, one of my colleagues is preparing a 40,000 word critical excursus on a reconstructed Shakespeare play.) Stanford University Press will soon offer "Stanford Briefs" of short original content of similar lengths. ${ }^{32}$ Anvil Academic Publishing, a joint venture from the Council on Library and Information Resources (CLIR) and the National Institute for Technology in Liberal Education (NITLE), is also beginning to experiment with familiar as well as new forms of publishing, including those which integrate digital collections and analysis tools unique to new media, as with their forthcoming series "Built Upon."

Such developments were never restricted to the digital domain. The literary press McSweeney's already produces bound books and pamphlets at these varied sizes, which notably are not shipped individually, but with the quirky magazine “issues” that McSweeney's releases. The 36th issue 
(2010) of McSweeney's Quarterly contains a wonderful assortment of printed stuff in various sizes, all delivered within a cubical cardboard box. The box is printed to look like a cartoonish and sweating human head and hinges at the top to access its contents: "A headful of new and unseen work." By analogy, the box is a material example of the dynamic between form and platform, how an alternative transmission system (the eReader, the web, the cardboard box) can drive new publishing genres. McSweeney's implicitly asks us to think inside the box for the fascinating array of published forms that could also reanimate scholarly publishing, forms that are made possible by multimodal distribution. The effects of these shifts are not limited to the digital. With its varied experiments, McSweeney's has realized how better to conceive and market the unique affordances

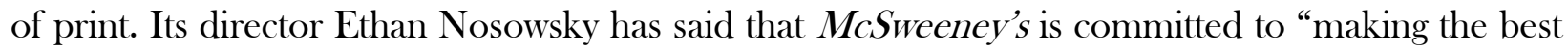
argument for the continued relevance of the printed book." ${ }^{34}$ Importantly, McSweeney's is not swimming against the digital tide but riding its material cross-currents. Because the digital remediation of books necessarily exposes what is special about print media, electronic publishing and distribution are driving innovation in book materials and design. Writing in The Guardian, Kathryn Hughes declared 2011 a "year of beautiful books" as publishers leveraged creative book design against the increasing market share of (unbeautiful) eBooks. ${ }^{35}$ Some publishers are experimenting with "hybrid books" in which the print object leads to multimodal digital extras called "illuminations." ${ }^{\prime 6}$ All of these experiments are testing the unique affordances of different media with boundary objects still called books.

But the possibilities of multimodal publishing and hybrid books have yet to reshape the scholarly monograph, even though, as Daly argues, "the ideal long-form scholarly publication is almost always one that is both digital and print-manifested; to date such bimodal material is not widely available, if at all." ${ }^{37}$ Ideally, a scholar should be able to access publications in different versions, but we should be careful to not let "bimodal" imply that print and digital are interchangeable media surrogates, as sometimes treated in library budgets and deaccessioning plans. Publications in multiple media can never be ideal, as textuality, authorship, and circulation vary significantly in each realm. To take only one perspective on this massive subject, Craig Mod sketches these differences in the "post-published" afterlife of digital works: "Mutability of artifact. Continuous engagement with readers. And most excitingly, a potentially public record of change, comment, discussion-digital marginalia-layered atop the artifact, adding to the artifact, and redefining 'complete." ${ }^{38}$ We can draw analogies between digital connectivity, mutability, and commentary and the realm of print media. But only to a point, because digital publishing requires a drastically different set of labor practices from production to evaluation to curation. These labor conditions, rather than specific technologies, offer the most profound challenges to reimagining those practices in the academy.

The dynamic between technological platform and scholarly practice has produced some recent monographs whose successes are measurable by traditional standards as well as speculative values. On the web, scholarly blogs and collaborative blogs are most public examples of digital academic production born of a platform. Blogs have generated books in trade as well as academic 
publishing, including respected monographs like Planned Obsolescence, Noah Wardrip-Fruin's Expressive Processing; or Siva Vaidhyanathan's The Googlization of Everything -an example not only of blog as proving grounds for a monograph, but a blog as its ongoing networked life once the book is printed. ${ }^{39}$ These examples have started to address the value or institutional legitimacy of blogging vis-à-vis the monograph as a scholarly activity. But "blog" means more than publishing drafts to the web. The term "blog" comprises a set of fairly discrete publishing and content management technologies, designed to database, distribute, aggregate, and recombine. Furthermore, courtesy of XML and "application programming interfaces" or APIs, blogs can interface with a range of additional content and functions on the web. With increasingly good scholarly content and an extensible platform, the web can generate new forms of academic media. The Mellon-funded project Anthologize was designed for exactly this: aggregating diverse webbased resources into printable books. Created in 2010 by humanities academics and programmers, Anthologize has since been elaborated into a digital publishing platform called PressForward. ${ }^{40}$ Going beyond the emphasis of Anthologize on the book, PressForward wants to promote highquality digital scholarship, to do it openly, and to develop user-friendly publishing engines to share with other scholars, societies, and academic publishers.

As PressForward shares its software, the range of its future applications will be determined by its users. That distributed strategy is driving Bob Stein's "Social Book" initiative. ${ }^{41}$ Stein, the former director of the Institute for the Future of the Book, bets that the future of publishing will not be about content but context. The Social Book model gives away web-based content for free but builds (and sells) enriched contextual structures around it. Basically, you can have the eBook but can also opt for additional features (at an escalating cost) such as expert annotations, social reading, and even personal contact with the author. The details of any given project are less important than Social Book's extensible platform. Unaffiliated users and publishers will be able to propose applications for Social Book, using it as a platform for their own enterprises. Social Book's model is less iTunes than App Store whose explosive success derives from its marketplace of applications. Ultimately, Social Book wants to be a platform not simply for a new kind of book, but for a new kind of publishing business. While academic publishing's success has never been commerciallydefined, this model at least asks what other social boundaries and contextual objects might newly describe scholarly publishing.

The integration of scholarly books with the web also suggests very different ways of thinking about composition, academic argument, and collaboration. As John Maxwell proposes, the academic book will only rediscover its authority "by a process of organic re-development, by way of going into the fluid webbiness of new media." ${ }^{42}$ For one thing, this means abandoning the term monograph for something like "multigraph": more than a pun, the term describes a network graph which permits multiple ways of connecting any of its nodes. ${ }^{43}$ At McGill University, the distributed participants of a research group called Interacting With Print recently convened for a conference devoted to writing a collaboratively-authored multigraph. While this outcome is still bookish, new platforms like Scalar are making possible the "fluid webbiness" of composing in new media. Born 
of the Vectors journal edited by Tara McPherson and Steve Anderson, Scalar invites scholars to compose with born-digital objects and allow multiple pathways through their work. Combining new media content with "rhizomatic plurality" in how readers use and interact with it, Scalar ambitiously tests us to consider what kinds of arguments, scholarly engagements, and institutional frameworks such forms of publishing allow. Work in digital humanities has further suggested how scholarly research and academic argument inhere in multimodal and non-linguistic forms, including coding, data, and visualizations. In such multimedia environments with such emerging forms of academic argumentation, the "book" may only shadow a locus of highly concentrated scholarship amidst variable flows of information and interdisciplinary professional networks. ${ }^{4}$

What will come to pass is unclear, a situation exacerbated by the number of possibilities for (and predictions about) the future. As Walter Benjamin trenchantly suggests, even the angel of history cannot forecast the storm called progress: "This storm irresistibly propels him into the future to which his back is turned, while the pile of debris before him grows skyward. ${ }^{{ }^{45}}$ For scholars, that debris has collected into radiant forms called books, significantly shaping the intellectual and disciplinary structures we have inherited. What will be the published legacy of my own generation of academics? Books, electronic and multimodal works, the contrails of our networked information practices? Does the academic press have a future than can even be deduced from its present? Will faculty be writing for the screen? Will my university's provost, upon reviewing a tenure application, ask that crucial question: "Does he have a blog?" I ask these questions not to answer for the monograph's future, but to underscore an array of factors-technological, methodological, institutional-affecting the books or media forms that we as humanities scholars continue to make.

Paul Fyfe

North Carolina State University

' George Bornstein, "Pages, Pixels, and the Profession," Journal of Scholarly Publishing 34, no. 4 (July 2003): 198.

2 "The Future of the Book as a Media Project," Cinema Journal 52, no. 2 (2013): 133.

3 "What Is a 'Book'? Some Post-Foucaldian Ruminations (a Prolegomenon)," Journal of Scholarly Publishing 34, no. 4 (July 2003): 183.

${ }^{4}$ Elena Pierazzo, "If I Read yet Another Article Entitled 'The Future of the Book' I Think I'll Die of Boredom-induced Perennial Lethargy \#enough,” Twitter, January 12, 2012, https://witter.com/\#!/epierazzo/status/164005530321428481. 
${ }^{5}$ "The Social Contract of Scholarly Publishing," Dan Cohen's Digital Humanities Blog, March 5, 2010, http://www.dancohen.org/2010/03/05/the-social-contract-of-scholarly-publishing/.

${ }^{6}$ "Epistemic System Break in Scholarly Monograph Publishing," New Media \& Society 15, no. 3 (2012), http://nms-theme.ehumanities.nl/uncategorized/epistemic-system-break-in-scholarlymonograph-publishing-pochoda.

${ }^{7}$ Greetham, "What Is a 'Book'?," 184.

${ }^{8}$ Pochoda points out that the golden age of scholarly monograph publishing only lasted a decade, and these downward trends started in the 1970s. See Pochoda, "Epistemic System Break in Scholarly Monograph Publishing.”

9 AAUP Task Force on Economic Models for Scholarly Publishing, Sustaining Scholarly Publishing: New Business Models for University Presses (New York: Association of American University Presses, March 2011), http://mediacommons.futureofthebook.org/mcpress/sustaining/; Carlos J Alonso et al., Crises and Opportunities: The Futures of Scholarly Publishing, 57 (New York: American Council of Learned Societies, 2003); Rebecca Ann Bartlett, "University Press Forum: Variations on a Digital Theme,” Journal of Scholarly Publishing 38, no. 4 (2007): 211 228; Laura Brown, Rebecca Griffiths, and Matthew Rascoff, University Publishing In A Digital Age (New York: Ithaka, July 2007), http://www.ithaka.org/ithaka-s-r/research/university-publishing-in-adigital-age/university-publishing; Peter J. Dougherty, "Reimagining the University Press: A Checklist for Scholarly Publishers," Journal of Electronic Publishing 13, no. 2 (Fall 2010), doi:http://dx.doi.org/10.3998/3336451.0013.202; Clifford Lynch, "Imagining a University Press System to Support Scholarship in the Digital Age," Journal of Electronic Publishing 13, no. 2 (Fall 2010), doi:http://dx.doi.org/10.3998/3336451.0013.207.

10 "Epistemic System Break in Scholarly Monograph Publishing."

11 "What Is a 'Book'?," 200.

${ }^{12}$ John Siracusa, "The Once and Future E-book: On Reading in the Digital Age," Ars Technica, February 1, 2009, http://arstechnica.com/business/2009/02/the-once-and-future-e-book-2/.

${ }^{13}$ Adeline Koh, "Are You a Press or Are You a Library? An Interview with NYU's Monica McCormick" The Chronicle of Higher Education, ProfHacker, March 27, 2012, http://chronicle.com/blogs/profhacker/press-or-library/39216.

${ }^{14}$ Meredith Morris-Babb, "Publisher Perspectives" (presented at the The Future of the Book, Florida State University, July 21, 2011).

${ }^{15}$ Monica Bulger et al., Reinventing Research? Information Practices in the Humanities (London: Research Information Network, April 2011), 6, http://www.rin.ac.uk/our-work/using-and-accessinginformation-resources/information-use-case-studies-humanities.

${ }_{16}$ Craig Mod, "Post-Artifact Books and Publishing," Craig Mod, June 2011, http://craigmod.com/journal/post_artifact/.

17 "Epistemic System Break in Scholarly Monograph Publishing.” 
${ }^{18}$ Several of the institute's "books" have worked this way, including Noah Warduip-Fruin's Expressive Processing: Digital Fictions, Computer Games, and Software Studies, which, revised after public and editorial comment, the MIT Press subsequently published in hard copy.

${ }^{19}$ Kathleen Fitzpatrick, Planned Obsolescence: Publishing, Technology, and the Future of the Academy (MediaCommons, 2009), sec. mla task force, http://mediacommons.futureofthebook.org/mcpress/plannedobsolescence/.

20 "Rotunda: New Digital Scholarship from the University of Virginia Press," The Unviersity of Virginia Press, 2004, http://rotunda.upress.virginia.edu/.

${ }_{21}$ "MPublishing," University of Michigan Libraries, 2012, http://www.lib.umich.edu/mpublishing.

22 "Amherst College to Launch First Open-access, Digital Academic Press Devoted to the Liberal Arts,” Amherst College, December https://www.amherst.edu/aboutamherst/news/news_releases/2012/12/node/445320.

${ }^{23}$ For just one example, see David Weinberger, Everything Is Miscellaneous: The Power of the New Digital Disorder (New York: Times Books, 2007), 9.

${ }^{24}$ Gita Manaktala, Bob Stein, and Christian Bök, "Reshaping the Book" (presented at the Unbound: Speculations on the Future of the Book, MIT, May 4, 2012), http://techtv.mit.edu/videos/19206-unbound-symposium-reshaping-the-book-may-4.

${ }^{25}$ Martha Nell Smith and Lara Vetter, eds., Emily Dickinson's Correspondences: A Born-Digital Textual Inquiry (Charlottesville: University of Virginia Press, 2008), http://rotunda.upress.virginia.edu/edc/.

${ }^{26}$ JoAnne Deeken, "An Academic Library as Publisher" (presented at the The Future of the Book, Florida State University, July 21, 2011).

${ }^{27}$ Liza Daly, "Digital Monograph Technical Landscape: Exemplars and Recommendations," The Digital Monograph Technical Landscape Study (\#jiscPUB), December 15, 2011, http://jiscpub.blogs.edina.ac.uk/final-report/.

${ }^{28}$ Ibid.

${ }^{29}$ Dan Cohen, "We Need Mechanisms for Right-sizing Scholarship," Twitter, July 14, 2011, https:/twitter.com/\#!/dancohen/status/91520749591990272; $\quad$ New-Model Scholarly Communication: Road Map for Change (University of Virginia Library: Scholarly Communication Institute, July 2011), http://www.uvasci.org/wp-content/uploads/2011/04/SCI9-report.pdf.

${ }^{30}$ Jennifer Howard, "'Princeton Shorts' Tries to Lure Readers With Digital Excerpts From Full Books," The Chronicle of Higher Education, October 30, 2011, sec. Hot Type, http://chronicle.com/article/Hot-Type-Princeton-Shorts/129579/; "Book Series: Chicago Shorts," The University of Chicago Press, 2013, http://press.uchicago.edu/ucp/books/series/CHISH.html.

${ }^{31}$ A contributing factor in moving Palgrave to innovate is its already established platform for digital distribution called Palgrave Connect. "Palgrave Macmillan Announces Palgrave Pivot," Palgrave Macmillan, 2011, http://www.palgrave.com/pivot/. 
${ }^{32}$ Cynthia Haven, “Bite-sized' Reading from SUP,” The Dish, May 17, 2012, http://news.stanford.edu/thedish/?p=19315.

${ }_{33}$ “Anvil Academic Publishing," National Institute for Technology in Liberal Education, 2012, http://www.nitle.org/help/anvil.php.

${ }^{34}$ Emma Gardner, "McSweeney's Ethan Nosowsky on How a Design-focused Publisher Goes Digital,” Lean Back 2.0, April 24, 2012, http:/www.economistgroup.com/leanback/lean-backreading/mcsweeneys-ethan-nosowsky-on-how-a-design-focused-publisher-goes-digital/.

${ }^{35}$ Kathryn Hughes, "Cover Story: a Year of Beautiful Books," The Guardian, December 2, 2011, sec. Books, http://www.guardian.co.uk/books/2011/dec/02/beautiful-book-covers.

${ }^{36}$ William Skidelsky, "21st-century Publishing Builds on a Healthy Radical Tradition," The Observer, December 17, 2011, sec. Books, http://www.guardian.co.uk/books/2011/dec/18/bookpublishing-digital-radical-pioneers.

${ }^{37}$ Daly, "Digital Monograph Technical Landscape: Exemplars and Recommendations."

${ }^{38}$ Mod, "Post-Artifact Books and Publishing."

${ }^{39}$ Noah Wardrip-Fruin, Expressive Processing: Digital Fictions, Computer Games, and Software Studies, Software Studies (Cambridge, Mass: MIT Press, 2009); Siva Vaidhyanathan, The Googlization of Everything: (and Why We Should Worry) (Berkeley: University of California Press, 2011), http://www.googlizationofeverything.com/.

${ }_{40}$ “Anthologize," Anthologize, 2010, http://anthologize.org/; “About,” PressForward, 2011, http://pressforward.org/.

${ }^{41}$ Bob Stein, "McLuhan Was Right" (presented at the The Future of the Book, Florida State University, July 21, 2011). For an example of Social Book being used in an academic context, see Jennifer Howard, "With 'Social Reading,' Books Become Places to Meet," The Chronicle of Higher Education, November 26, 2012, sec. Technology, http://chronicle.com/article/SocialReading-Projects/135908/; “Open Utopia,” The Open Utopia, 2012, http://theopenutopia.org/. Another social reading platform is being used for the online version of Matthew K Gold, ed., Debates in the Digital Humanities (Minneapolis: University of Minnesota Press, 2012), http://dhdebates.gc.cuny.edu/.

${ }^{42}$ Original emphasis. "Pressbooks, Monographs, and the Essence of the Book," Publishing@SFU, November 22, 2012, http:/www.ccsp.sfu.ca/2012/11/pressbooks-monographs-book-essence/.

${ }^{43}$ Tim McCormick, "From Monograph to Multigraph: The Distributed Book," Tjm.org, January 4, 2013, http://tjm.org/2013/01/04/from-monograph-to-multigraph-the-distributed-book/.

${ }^{44}$ Douglas Armato, "From MLA 2013: Considering Serial Scholarship and the Future of Scholarly Publishing," University of Minnesota Press Blog, January 7, 2013, http://www.uminnpressblog.com/2013/01/from-mla-2013-considering-serial.html.

${ }^{45}$ Walter Benjamin, "Theses on the Philosophy of History," in Illuminations, ed. Hannah Arendt, 1st ed. (New York: Harcourt, Brace \& World, 1968), 260. 